Article

\title{
The Mediating Role of Intellectual Capital in Open Innovation in the Service Industries
}

\author{
Chihcheng Lo ${ }^{1, *(\mathbb{D})}$, Chunhsien Wang ${ }^{2}$ and Yi-Chun Chen ${ }^{1}$ \\ 1 Industrial Education and Technology, National Changhua University of Education, Changhua City 500, \\ Taiwan; d9659286@gmail.com \\ 2 Department of BioBusiness Management, National Chiayi University, Chiayi City 600, Taiwan; \\ chwang@mail.ncyu.edu.tw \\ * Correspondence: charleslo@gm.ncue.edu.tw
}

Received: 31 May 2020; Accepted: 23 June 2020; Published: 26 June 2020

check for updates

\begin{abstract}
The paper intends to examine the mediating role of intellectual capital in the relation between the openness of service companies' search strategies and thr innovation performance. It models the relationship between external search strategies of open innovation and proposes how intellectual capital matters for openness strategies in the service industries. Moreover, the paper intends to expand the field of open innovation through exploring the mediating effect of intellectual capital. This paper fulfills an identified need to study how intellectual capital can be enabled in the open innovation of the service industries. Both Hierarchical Multiple Regression and the Structural Equation Model were employed to test the innovation model by the panel data of the second Taiwan Innovation Survey including 948 service firms. Empirical insights enable us to have a better understanding in terms of how service companies learn from external knowledge sources. This paper suggests that the impact of openness strategies on innovation performance becomes indirect through the partial mediator of intellectual capital so that innovation performance in service industry benefits from simultaneously incorporating intellectual capital with the efficient openness strategies. Finally, the paper includes implications for more insights into how service companies improve their innovative activities with external searching strategies and practices in terms of intellectual capital.
\end{abstract}

Keywords: open innovation; intellectual capital; innovation performance

\section{Research Background and Motivation}

Since Chesbrough [1] characterized an open innovation paradigm as a method of collaborating with external innovation sources by companies to develop new products or services, the influence of open innovation activities has attracted a lot of attention in the literature on entrepreneurship. Previous studies in the service industry [2,3] have shown that innovation strategies are not likely to come up with any automated approach toward a higher or lower level of openness; service companies that innovate at the external knowledge level are required to develop a compatible capability. This study highlights the importance of intellectual capital in the era of open innovation in the service industry, which includes organizational, social and human capital. The intellectual capital literature emphasizes that knowledge may create more competitive advantage than that of other tangible capital in the service industry [4]. How intellectual capital can be beneficial to open service innovation is the main research objective of this paper. Therefore, the paper intends to explore the mediating role of intellectual capital in the relation between the openness of companies' external search strategies and their innovative activities. We model the association among the three different external search strategies and innovation performance, and how practices matter for open innovation while drawing attention to the notion of complementarities with intellectual capital. Moreover, the study aims to expand the implicated 
field of open innovation through exploring possible mediators related to the intellectual capital in the service industries.

The sample of the study is based on the Taiwan service firms in the second Industrial Innovation Survey in Taiwan Area (hereafter as Taiwan Industrial Innovation Survey, TIIS). National Science Council employed a second large-scale innovation survey, which included enterprise size, the amount of turnover, the firm's major markets, the firm's major customers, the degree of innovation, sources of innovation, explore innovation impact and so on. We constructed a dataset including 948 service firms. While many factors can affect innovation in the service industry, there is little empirical study by TIIS discussing the association between the types of innovation and the degree of openness in the service industry. An open innovation paradigm advocates a new approach of collaborating with external sources to develop new products or services; the influence of open innovation activities has attracted a lot of attention in Taiwan during the TIIS survey. This empirical study during the period allows us to understand more in-depth transformation in Taiwan's service industry and its value at the beginning of open innovation era.

Successful service companies are required to leverage a lot of resources to identify new market opportunities. With a fast-changing service market, simply preserving internal resources does not guarantee to maintain a competitive advantage, particularly in the transformation of manufacturing to a service industry in Taiwan [5]. Limited empirical studies so far have explained how openness strategies facilitate innovative activities related to economic transformation in the new emerging market. We empirically examine the relation between the external search and innovative performance, such as searching widely and deeply, and decipher how differences in terms of external search strategies among service companies. Particularly, the main objective of the study aims to explore how enterprises deploy intellectual capitals in the relation between openness strategies and innovative activities. According to the research objectives, we focus on the following question: what level of the intellectual capital of a company is regarded as the basis for the open innovation that creates a company's competitiveness in the service industries. In brief, what degree of openness is essential in innovation performance in terms of the intellectual capital in Taiwan service industries?

\section{Literature Review and Hypothesis Development}

The innovation process and performance between manufacturing and service sector has been different. While manufacturing sector is much more linear and direct to product or production, service sectors are more concerned with marketing opportunities which are also identified as an innovation of using services to sell more products [6]. Innovation is one of the key methods of companies adapting to and managing their environments. However, while entrepreneurial strategy, network ties, and financial capital have a significant effect [7], human capital are not clearly associated with organizational performance $[7,8]$. However, both manufacturing and service sector have been shifted from product-centric to service-centric thinking, when co-creating with customers has been an important drive in the value creation of sustainable business models, such as the improvement of service quality and an appropriate reasonable price [9]. In sum, service innovation has obtained more attention due to its potential value for the creation of a competitive advantage and improvement of organizational performance.

The main source of successful service innovation is based on a variety of ideas from anywhere with an open environment. That is, service companies, such as the tourist industry, are required to associate with their external sources of entrepreneurs knowledge to acquire capitals and talents, ideas from either inside or outside a company [10]. Previous studies have shown the paradigm shift from closed to open innovation models [11,12]. Open innovation is beneficial for the innovative performance when companies need to spend a lot of costs related to all searching, coordinating and monitoring new ideas, such as market know-how, in the competitive market. At the same time, the construction of path-dependent knowledge within a company may also hamper the development of innovation [12]. Therefore, a firm's absorptive capacity plays an essential role in enhancing firms' innovation, such as 
the management capability of intellectual capital. Huang and Rice [11] found a significant relationship between absorptive capacity and innovation performance, such as access to new markets $[11,12]$. In this regard, open innovation is a paradigm shift from creating and hoarding innovations internally to accessing and integrating external knowledge. Service firms have a degree of openness to search value idea from outside to form or transmit new service to market. The study of Cammarano, Caputo, Lamberti and Michelino [13] show that the diversified effect of OI activities on firms' knowledge strategies and innovation outputs and highlighted the role intellectual property management capability in a new ICT company's innovation.

However, while most empirical studies highlight the importance of intellectual capital in the manufacturing sector, a contingent conceptual model is required to have more understanding of the role of intellectual capital for service firms in order to enhance their innovative capabilities. Mina, Bascavusoglu-Moreau and Hughes [14] show that business services are more active open innovators than manufacturers, particularly in informal relative to formal practice. This paper focuses on open innovation in services industries, which is a subsector of the knowledge economy. The paper therefore employs a proxy variable for the openness strategies in the service industries to explore the relation between indicators of performance and external search strategies in terms of open innovation.

\subsection{Openness Strategies and Innovation Performance}

Openness strategies have increasingly become a phenomenon in the literature of innovation management. Firms intends to collaborate, or source with specific partner organizations in order to exchange knowledge and to commercialize embodied knowledge. Barge-Gil [15] analyzed different approaches, including transaction costs, competences, and open innovation and found that optimum level of openness manifests differently in line with different approaches. For example, semi-open strategies are positively correlated to a higher performance than closed ones in Spanish firms. Therefore, the empirical finding of different countries on innovation activities in the service sector are diverse, and more empirical study from different countries are needed.

In addition, the degree of leveraging open innovation dimensions depends on a variety of factors, such as complementarity and internal R\&D. Both external technology acquisition and external technology exploitation have a positive influence on firms' performance under situation of higher internal research and development spending [16]. Therefore, this paper analyses the openness strategy based on the study of Laursen and Salter [17]. In doing so, the construct of openness strategies is defined as a breadth and depth strategy in the service industry. Breadth denotes the variety of partners or activities, and depth strategy accounts for the intensity of the openness strategy [17].

The breadth of openness strategy designates how many external sources or channels in terms of innovation activities service companies rely on. These sources or channels are the bases of firms' innovative activities [17]. The heterogeneity of these sources is required to fulfil the company's the need of product development and commercialization processes, for example, firms may acquire or transfer outside $R \& D$ resources to co-develop product or process innovation.

In addition, the depth of openness strategy denotes external search depth in terms of the extent to which service companies draw deeply from the diverse external source search channels. Accordingly, the construction of depth employed the same 16 sources of knowledge from TIIS as those used in above Breadth [17]. Based on the TIIS, each of the 16 sources is coded with 1 when the company answers that the source is exploited to a high degree and 0 in the case of no, low, or medium use of the given source. In this regard, the depth of openness explains that how intensive the outside contribution is by a focus on high degree of contribution.

Finally, the indicator of depth-collaboration has combined above two indicators because companies may need keep intensive and confidential to outsiders in order to transfer knowledge [17]. The indicator of "Depth-Collaboration" has a formal innovation interaction with different external sources. These external sources of service companies might contain their suppliers and customers, competitors, outside consultants, commercial laboratories, universities, government research organizations, or private 
research institutes. The inter-organizational interaction may result in processes of mutual learning and adaptation.

While companies in service industry adopts either or both depth and scope of an external search strategy to explore new knowledge and to exploit existing knowledge from external sources, this paper could further evaluate the openness strategies of a company's search activities. With this in mind, firms have to work out their skills and openness capacity. However, Cammarano et al. [13] suggest that the diversified effect of OI activities might have on firms' innovation outputs. As a result, Lopes et al. [18] a contingent conceptual model is required to explain the relationship between open innovation and performance. Therefore, both the degree of scope and depth of search processes have a crucial role in shaping success in open innovation [4,19]. First hypothesis as follows:

Hypothesis 1. Open innovation strategies breadth, depth, depth-collaboration has a positive correlation for innovation performance in the service industries.

\subsection{The Mediating Role of Intellectual Capital on Open Innovation}

While school of intellectual capital highlights knowledge is an important source to business performance and competitiveness than that of physical assets [20], empirical evidence on the relations between intellectual capital and innovation are still relatively meager [21]. Intellectual capitals are highly related to a company's innovation capability, which enhance companies' ability to utilize knowledge resources. As for service industry, Chaston [22] show that Independent financial advisors' involvement in networks and open innovation improve business performance. In this regard, the effect intellectual capital on companies' innovation capability has been associated with organizational capital, social capital, and human capital.

First, human capital at an individual level refers to the knowledge and capabilities of employees who belong to the firm. Human capital is associated with the employee factors, such as commitment, motivation, and skill. Knowledge and skill employee create a unique value to the firm. Second is organizational capital means the preservation of knowledge generated within the firm through formal processes of proper knowledge management [23]. Organizational capital is triggered by knowledge integration to combine different technological skills [24,25]. Third is Social capital. Social capital is regard as an outcome of collaboration and interaction among those people who share their ideas [26]. For example, Suseno and Rowley [26,27] highlights the role of social capital in service industries, particular in the internationalization of service firms. With this in mind, service firms are increasingly relied on external collaboration in securing competitive advantage and enhancing their innovative capabilities [27]. Based on the literature review, we develop the following hypothesis:

Hypothesis 2. Open innovation strategies breadth, depth, depth-collaboration have a positive correlation in intellectual capital.

Intellectual capital has been a crucial factor for an organization's potential of development. Intellectual capital, with human capital, social capital, and organizational capital, are through the various elements of the tie in order to create business value and enhance innovation performance $[4,28]$. In addition, Theoretical and empirical studies show that the unique combination of the different elements of intellectual capital also determine a competitive advantage of service innovation. This paper therefore aggregates above three dimensions into an intellectual capital. While the substantial literature on intellectual capitals produced in recent years, there have been fewer attempts to empirically examine the mediating role of intellectual capitals within the service industry with their openness strategies. Therefore, we posit the following hypothesis:

Hypothesis 3. Intellectual capital is mediating between open innovation strategies and innovation performance. 


\section{Research Methodology and Measurement}

\subsection{Population and Sampling Strategy}

The dataset used for the study derive from the survey of Taiwan service firm conducted by the National Science Council's project, namely, the Second Industrial Innovation Survey in Taiwan Area (TIIS) from 2004 to 2006 [29]. The questionnaire of TIIS is based on the specifications of the European Innovation Survey (Community of Innovation Survey, CIS). Although the new dataset of TIIS enable us to construct and test more complicated behavioral models, the availability of new data sources might also raise a new issue in terms of diverse development of open innovation. For example, reflecting the transformation of the Taiwan economic development, the period of TTIS has presented the emerging of service, in particular the Servitization of Taiwan high-technology industries [3,5,30].

TIIS employed a telephone survey and face-to-face interviews. The company has more than 6 employees and innovation activities in the period (2004-2006). Since the paper focuses on service industries innovation, the sample for this study includes 4089 public-listed service. Of these, 948 valued questionnaires were collected by TIIS, while a response rate is 24 percent.

\subsection{Independent Variables}

The independent variables were depth, breadth, and collaboration. From the Taiwan community innovation survey to identify the matching indicator items, each item adds up to be higher the score, the higher the degree of openness, the lower the degree of openness of the lower scores. Three variables reflect openness in terms of external search strategies of firms and its relation to factors of innovative performance. According to Laursen and Salter [17], each of the 16 sources from TIIS is coded as a dummy variable. While 0 represents no use of external source, and 1 represents the only use of the given knowledge sources. For example, both breadth and depth uses the eight dummies which are subsequently added up. In this case, each company gets a score of 0 when no source is used, while the company has a value of 8 when the company is collaborating with all sources. With the same source, the indicator of depth-collaboration measure whether or not the company in question has formal innovation collaboration links with different external sources.

\subsection{Dependent Variable}

We measure innovative performance by the diversity of innovation activities, including two forms of product and service innovations: new product or service development, improvement of existing products or services. The fraction of the firm's turnover in terms of products new to the world market is used to measure radical innovation. In addition, we add two variables as proxies for incremental innovation. Both the fraction of the firm's turnover relating to products new to the companies, and the fraction of the firm's turnover relating to products significantly improved are used to measure incremental innovation.

\subsection{Mediating Variable}

Mediation exists when the influence of an independent variable (open innovation) on a dependent variable (innovation performance) is transmitted through a mediator (intellectual capital). Actual partial mediation exists when open innovation exerts both direct and indirect effects on innovation performance.

We use intellectual capital to reflect various types of meditating effects by firms. Intellectual capital generally includes three items: first, social capital represents that greater knowledge is embedded in relationships among individuals. Second, human capital, including employee's skills, experience, and knowledge, is related to the development of organizational knowledge. Third, knowledge of organizational capital is embedded in structures, systems, process [24,25,31]. Since such measures exist at the individual level, the above variables are measured by TIIS using indicators. This measurement of intellectual capital aggregates involves three dimensions in the notion of intellectual capital. 


\subsection{Control Variables}

Previous studies suggest that control variables that influence the innovative performance of a firm are the size of firms and a firm's revenue. The size of firms means the number of firm employees, and firm's revenue means total cash flow [32]. Both of the above-mentioned variables are included in the logarithmic form.

To sum up, four stages were conducted in the study to develop a model of model development, testing and explanation approaches. Stage one begins with the construction of the survey; at stage two we employed exploratory and confirmatory factor analysis for scale construction and validation; stage three involved the application of Hierarchical Multiple Regression (HMR) and a structural equation model (SEM) to test the model, and finally, stage four allowed us to further probe the model and test hypotheses.

\subsection{Conceptual Framework}

In this section, the database from The Third Industrial Innovation Survey in Taiwan Area is used. We describe the use of structural equation modeling (SEM) to test the hypotheses identified earlier. The study controls for several variables that prior research has indicated might be relevant for this model. The study investigated the degree of open innovation using variables including DEPTH, BREADTH, and DEPTH-COLLAB, and the independent variables were Social capital, Organization capital, Human capital, and innovation performance for the statistical analysis. SEM includes confirmatory factor analysis and investigates relationships within and between grouped data more efficient at accounting for variance among variables. A form of causal modeling can be then interpreted so that claims about the constructs can be made, based on the best fitting model with caution. These indicators, including openness strategy and intellectual capitals, are regarded to improve performance in the service industry. Therefore, our research model focuses on three key openness strategies depth, breadth, and depth-collab. We also examine the role of intellectual capital in service industry and explain how the intellectual capital mediate the three types of openness strategy and innovation activities (Figure 1).

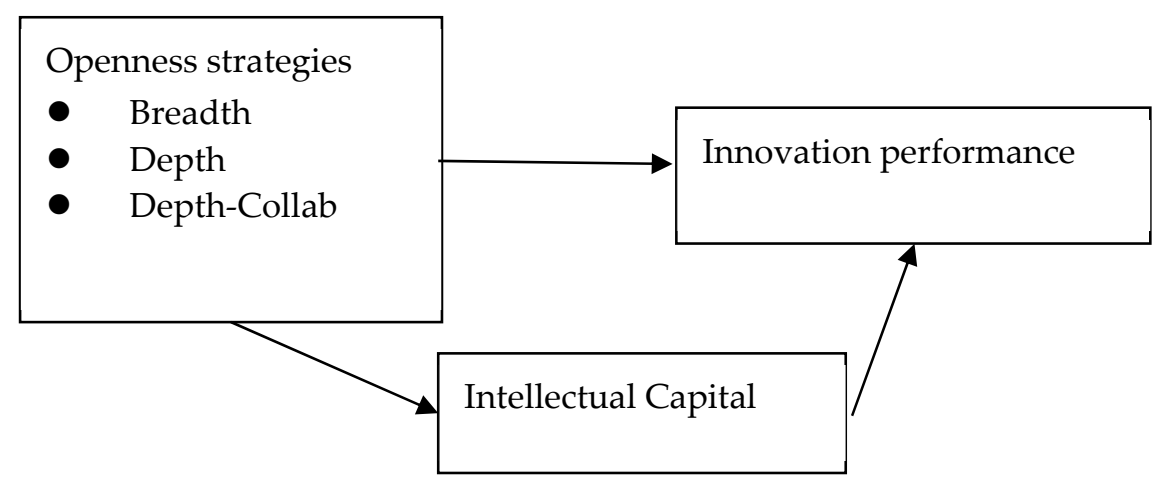

Figure 1. Conceptual framework.

\section{Empirical Results and Discussion}

Table 1 shows the means and standard deviations. The sample for this study includes 4089 publicly listed service firms. Of these, 948 usable questionnaires were returned, for a response rate of $24 \%$. Of the following respondents $(N=948)$, the firm size is controlled by the study based on the Directorate-General of Budgets, Accounting and Statistics' Industry Standard Classification of employees, that is, number 1 represents less than 5 employees; number 2 represents 5-29 employees; number 3 represents 30 to 49 employees; number 4 represents 50 to 199 employees; number 5 represents 200-499 employees; 6 represents 500 or more employees. Breadth means was $5.4(\mathrm{SD}=4.665)$, depth mean was 2.37 ( $\mathrm{SD}=3.149$ ), depth-collaboration mean was $4.49(\mathrm{SD}=3.25)$. Intellectual capital's mean was 2.84 (SD $=1.108)$. The mean of innovation performance was $19.94(\mathrm{SD}=9.397)$. 
Table 1. Descriptive statistics $n=948$.

\begin{tabular}{ccccc}
\hline & Min & Max & Mean & SD \\
\hline Firm-size & 4 & 6 & - & - \\
Breadth & 0 & 10 & 5.4 & 4.665 \\
Depth & 0 & 8 & 2.37 & 3.149 \\
Depth-Collaboration & 0 & 9 & 4.49 & 3.25 \\
Intellectual Capital & 2 & 4 & 2.84 & 1.108 \\
Innovation Performance & 6 & 36 & 19.94 & 9.397 \\
\hline
\end{tabular}

Table 2 shows the means and standard deviations, and bivariate Pearson correlations among breadth, depth, depth-collaboration, social capital, human capital, organization capital. The significant positive correlations with variables were all over $0.625(p<0.01)$, showing that all of the sub-dimensions of openness degree correlated positively with the intellectual capital. In addition, the correlations for all of the sub-dimensions of openness degree and innovation performance are also significantly positive and are all over $0.8(p<0.01)$.

Table 2. Descriptive statistics and bivariate Pearson correlations $n=948$.

\begin{tabular}{ccccccccc}
\hline & Mean & SD & $\mathbf{1}$ & $\mathbf{2}$ & $\mathbf{3}$ & $\mathbf{4}$ & $\mathbf{5}$ & $\mathbf{6}$ \\
\hline 1. Firm-size & 5.42 & 0.69 & 1 & & & & & \\
2. Breadth & 5.4 & 4.66 & $0.89^{* *}$ & 1 & & & & \\
3. Depth & 2.37 & 3.14 & $0.62^{* *}$ & $0.73^{* *}$ & 1 & & & \\
4. Depth-Collaboration & 4.49 & 3.25 & $0.86^{* *}$ & $0.91^{* *}$ & $0.88^{* *}$ & 1 & & \\
5. Intellectual capital & 2.84 & 1.10 & $0.93^{* *}$ & $0.94^{* *}$ & $0.74^{* *}$ & $0.93^{* *}$ & 1 & \\
6. Innovation Performance & 19.94 & 9.39 & $0.80^{* *}$ & $0.88^{* *}$ & $0.92^{* *}$ & $0.97^{* *}$ & $0.89^{* *}$ & 1 \\
\hline \multicolumn{8}{c}{ Note: } \\
\end{tabular}

This paper tested mediating by three regression equations: to begin with regressing the mediator on the independent variable, and then we regressed the dependent variable on the independent variable; and finally, we employ a regression with the dependent variable on both the independent variable and on the mediator. As suggested by the literature [33], separate coefficients for each regression were examined.

In Table 3, the hypothesis was tested by hierarchical models by providing an estimate of the total variance. First of all, we included firm size (number of employees) as control variables $(\beta=0.8$, $p<0.001$ ). Next step, by the model 2 , openness strategies have a significant positive influence on intellectual capital $(\beta=0.141, p<0.01 ; \beta=0.172, p<0.01, \beta=0.702, p<0.01)$, the overall model pattern also reached significance.

Table 3. Results of hierarchical regression analysis.

\begin{tabular}{cccccc}
\hline \multirow{2}{*}{ Variable } & \multicolumn{5}{c}{ I.C. Innovation Performance } \\
\cline { 2 - 6 } & Model 1 & Model 2 & Model 3 & Model 4 & Model 5 \\
\hline Firm size & $0.800^{* * *}$ & $0.011^{* * *}$ & $-0.045^{* * *}$ & $0.037^{* * *}$ & $-0.079^{* * *}$ \\
Breadth & & $0.141^{* * *}$ & $0.13^{* * *}$ & & $0.073^{* * *}$ \\
Depth & & $0.172^{* * *}$ & $0.308^{* * *}$ & & $0.271^{* * *}$ \\
Depth-Collaboration & & $0.702^{* * *}$ & $0.62^{* * *}$ & & $0.462^{* * *}$ \\
I.C. & & & & $0.224^{* * *}$ & $0.139^{* * *}$ \\
$R^{2}$ & $0.64^{* * *}$ & $0.991^{* * *}$ & $0.966^{* * *}$ & $0.961^{* * *}$ & $0.967^{* * *}$ \\
$\Delta R^{2}$ & & $0.226^{* * *}$ & $0.326^{* * *}$ & $0.321^{* * *}$ & $0.001^{* * *}$ \\
\hline
\end{tabular}

Note: 1 . Firm size $=$ Log of number of employees; 2 . I.C. = "Intellectual Capital"; $3 .{ }^{*}$ indicates $p<0.05 ;{ }^{* * *}$ indicates $p<0.001$. 
As for the model 3 , the three traits of openness strategies were entered, both breadth $(\beta=0.13$, $p<0.001)$, depth $(\beta=0.308, p<0.001)$ and depth-collaboration $(\beta=0.62, p<0.001)$ became significant predictors. As for the model 4 , when organization capital and human capital were added to the equation, both organization capital $(\beta=0.809, p<0.001)$ and human capital $(\beta=0.204, p<0.001)$ emerged as significant predictors

With the final models, empirical study shows that breadth $(\beta=0.073, p<0.001)$, depth $(\beta=0.271$, $p<0.001)$, depth-collaboration $(\beta=0.462, p<0.001)$, and the organization capital $(\beta=0.146, p<0.001)$ and human capital $(\beta=0.139, p<0.001)$ are significant predictors.

Table 3 shows, after adding mediation variables, the $\beta$ of independent variables (breadth depth, depth-collaboration) dropped, but still had a significant impact, which indicated that the indirect effect of intellectual capital was statistically significant $(p<0.001)$. Empirical results showed that the intellectual capital in openness strategies has a significant impact on innovation activities with a partial mediating effect.

\subsection{Common Method Variance}

This study adopted a Confirmatory factor analysis (CFA) test to examine the extent to which our variables were influenced by common method variance. CFA is regarded as a more refined test of the hypotheses due to the reason that a single factor can account for all of the variance in the data $[33,34]$. Multiple-factor CFA analysis results show $\chi^{2}=1851.43, \mathrm{df}=64, \chi^{2} / \mathrm{df}=28.93, \mathrm{GFI}=0.802$, AGFI $=0.675, \mathrm{CFI}=0.931, \mathrm{RMSEA}=0.172, \mathrm{TLI}=0.902$.

\subsection{Measurement Model}

This study used six model-fit measures to investigate the model's overall appropriateness of fit: the ratio of chi-square to degrees of freedom, goodness of fit index (GFI), root-mean-square residual (RMR), normed fit index (NFI), comparative fit index (CFI), and root mean square error of approximation (RMSEA) [33,34]. The above six indicators are designed from original measure items for each of the latent constructs by maximizing each construct's share variance.

Table 4 shows factor loadings and squared multiple correlations of remaining items for all constructs. Reliability of our construct scales was estimated through composite reliability [35]. The composite reliabilities for the five constructs scales are proposed as acceptable reliability of the scales for following analysis (breadth: 0.959, depth: 0.968, depth-collaboration: 0.975, intellectual capital: 0.925 , performance: 0.975$)$. We assessed the reliability of each scale by calculating composite reliability (C.R.) and average variance extracted (AVE). Firstly, Table 4 evaluated convergent validity by investigating the factor loadings of indicators and their squared multiple correlations (SMC). As Hair et al. [35] suggested, factor loadings greater than 0.50 are regarded as very significant. Table 4 shows that all factor loadings are greater than 0.50. The measurement model has an adequate convergent validity in terms of all constructs. In addition, we employed AVE for each dimension to measure the level of variance of a construct versus the level due to measurement error [36]. Table 4 shows that values of AVE for each dimension is above 0.7 , which are considered very well. This implied that the unconstrained model is a better fit for the data, thus supporting the existence of discriminant validity. Therefore, Table 4 suggest that no further deletion of items is necessary. 
Table 4. Factor loadings and squared multiple correlations of remaining items for all constructs.

\begin{tabular}{cccccc}
\hline Construct & Observation Variable & Factor Loadings & SMC & C.R. & AVE \\
\hline \multirow{3}{*}{ Breadth } & A4 & 0.9 & 0.8 & & \\
& A8 & 1 & 1 & 0.959 & 0.885 \\
& A9 & 0.92 & 0.85 & & \\
\hline \multirow{3}{*}{ Depth } & B1 & 0.97 & 0.95 & & \\
& B2 & 0.89 & 0.79 & 0.968 & 0.911 \\
& B10 & 1 & 1 & & \\
\hline \multirow{3}{*}{ Depth-Collaboration } & C5 & 0.93 & 0.86 & & \\
& C7 & 0.96 & 0.92 & 0.975 & 0.929 \\
& C8 & 1 & 1 & & \\
\hline \multirow{3}{*}{ Intellectual capital } & HC & 0.99 & 0.99 & & \\
& OC1 & 0.9 & 0.82 & 0.925 & 0.805 \\
Innovation & OC2 & 0.79 & 0.63 & & \\
\hline Performance & IP1 & 0.98 & 0.96 & & \multirow{2}{*}{0.929} \\
& IP3 & 0.93 & 0.86 & 0.975 & 0.929 \\
\hline
\end{tabular}

\subsection{Structural Model Fits}

According to Table 5, the hypothetical structural model fits the data $\left(\chi^{2}=3130.53 ; \mathrm{df}=64\right.$, $\chi^{2} / \mathrm{df}=48.915, p<0.01, \mathrm{GFI}=0.741, \mathrm{AGFI}=0.576, \mathrm{NFI}=0.906, \mathrm{CFI}=0.917, \mathrm{IFI}=0.917$, RMSEA $=0.225$ ). In general, Hypothesis 1 investigates the path from openness strategies to innovation performance. The analysis suggested that intellectual capital $(\beta=0.808, t=38.133, p<0.001)$ showed a strong, positive association with intellectual capital. Hypothesis 1 was supported. In addition, Hypothesis 2 examines the path from open innovation strategies to intellectual capital. The analysis suggested that organizational intellectual capital $(\beta=1.032, t=63.599, p<0.001)$ showed a strong, positive association with intellectual capital. Hypothesis 2 was supported. Finally, the structural model enables us to examine the predictive power of open innovation on intellectual capital. As seen in Table 5, Hypothesis 3 investigates the significance of the standardized path from intellectual capital to innovation performance. The analysis suggested that intellectual capital $(\beta=0.17, t=10.512, p<0.001)$ was associated with innovation performance.

Table 5. Model paths and moderation estimates.

\begin{tabular}{ccc}
\hline Path & Standardized Estimates & C.R. \\
\hline $\begin{array}{c}\text { H1: Openness strategy } \\
\rightarrow \text { Innovation Performance }\end{array}$ & 0.808 & $38.133^{* * *}$ \\
\hline $\begin{array}{c}\text { H2: Openness strategy } \\
\rightarrow \text { Intellectual Capital }\end{array}$ & 1.032 & $63.599^{* * *}$ \\
\hline $\begin{array}{c}\text { H3: Intellectual Capital } \\
\rightarrow \text { Innovation Performance }\end{array}$ & 0.17 & $10.512^{* * *}$
\end{tabular}

Note: $1 . \chi^{2}=3130.53 ; \mathrm{df}=64, \chi^{2} / \mathrm{df}=48.915, p<0.01, \mathrm{GFI}=0.576, \mathrm{CFI}=0.917, \mathrm{IFI}=0.917, \mathrm{NFI}=0.906$, RMSEA $=$ $0.225) ; 2 .{ }^{* * *}$ indicates $p<0.001$.

\section{Conclusions and Suggestions}

By investigating the role of intellectual capital in open innovation, this paper has revealed the string of inquiries. We seek to broaden the conceptual understanding of external search processes in service firms. Service companies need to master users' specific knowledge that include technologies and markets in terms of the service innovation process. To acquire more understanding of how service firms draw knowledge from external sources, this study inspected weather the intellectual capital plays a mediating role between openness level innovation performance or not. Indeed, searching 
widely and deeply across a variety of search channels can provide ideas and resources to gain and exploit innovative opportunities.

Further study is encouraged to follow the above line of inquiry to bring more insights into how service firms enhance their innovation performance with well-designed search strategies and practices in terms of intellectual capital. For example, organizational learning capability has been mentioned in the recent study as a mediating variable in the manufacturing sector [31]. An open model of service innovation can improve search capabilities to locate new sources from intellectual capital. These capabilities may be further enhanced by a more mindful application of search strategies. We finally provided a broader picture of the implications of intellectual capital in service-oriented firms.

With the transformation of industrial economies, the Taiwanese information technology industry has to upgrade from a production to an innovation orientation [30]. The paper seeks to explore the role of intellectual capital in the emerging period of the Taiwanese service industry. In brief, this paper enables us to have a more detailed understanding of what kind of intellectual capital is embedded in the Taiwanese service industry and how the intellectual capital is managed effectively. Our findings exhort scholars to investigate innovation practices at the intellectual capital domain level in order to detect specific behaviors. The point is to sort out how the Taiwanese service industry should start to accumulate or enhance the intellectual capital for future competitive advantage.

As for the limitations of this study, the targeted companies were major large-sized firms in the service industry and thus, the smaller Taiwanese companies were excluded. A large company has its own specific characteristics, whereas short lifespan smaller size company data were not collected. Thus, readers should be cautious about generalizing the findings of this paper to the implications for small and medium companies. In addition, when a number of cross-sectional units over time in following TIIS have become available, the new dataset of innovation survey might enable us to compare more complicated behavioral models than the findings of this paper would offer. Further study could use the availability of new data sources to indicate areas of research where panel data may be useful. While literature has showed a curvilinear relationship between external search depth and innovative performance, further research is needed to examine how exactly co-developmental processes between intellectual capital and openness strategy affect a firm's performance needs in the future.

Author Contributions: Conceptualization, C.L. and Y.-C.C.; methodology, C.L. and C.W.; validation, C.L., C.W. and Y.-C.C.; formal analysis, Y.-C.C.; investigation, C.L. and Y.-C.C.; data curation, Y.-C.C.; writing-original draft preparation, C.L. and C.W.; writing-review and editing, C.L. All authors have read and agreed to the published version of the manuscript.

Funding: This research received no external funding.

Conflicts of Interest: The authors declare no conflict of interest.

\section{References}

1. Chesbrough, H. Open Innovation: The New Imperative for Creating and Profiting from Technology; Harvard Bus. School Press: Boston, MA, USA, 2003.

2. Rodriguez, M.; Doloreux, D.; Shearmur, R. Innovation strategies, innovator types and openness: A study of KIBS firms in Spain. Serv. Bus. 2016, 10, 629-649. [CrossRef]

3. Baines, T.; Bigdeli, A.Z.; Bustinza, O.F.; Shi, V.G.; Baldwin, J.; Ridgway, K. Servitization: Revisiting the state-of-the-art and research priorities. Int.J. Oper. Prod. Manag. 2017, 37, 256-278. [CrossRef]

4. Prajogo, D.I.; Oke, A. Human capital, service innovation advantage, and business performance. Int. J. Oper. Prod. Manag. 2016, 36, 974-994. [CrossRef]

5. Lin, C.Y.-Y.; Mavis, Y.-C.C. Does innovation lead to performance? An empirical study of SMEs in Taiwan. Manag. Res. News 2007, 2007, 115-132.

6. Kastalli, I.V.; Van Looy, B. Servitization. Disentangling the impact of service business model innovation on manufacturing firm performance. J. Oper. Manag. 2013, 31, 169-180. [CrossRef]

7. Khan, N.U.; Li, S.; Safdar, M.N.; Khan, Z.U. The role of entrepreneurial strategy, network ties, human and financial capital in new venture performance. J. Risk Financ. Manag. 2019, 12, 41. [CrossRef] 
8. Olson, E.M.; Slater, S.F.; Hult, G.T.M.; Olson, K.M. The application of human resource management policies within the marketing organization: The impact on business and marketing strategy implementation. Ind. Mark. Manag. 2018, 69, 62-73. [CrossRef]

9. Chen, C.M.; Liu, H.M. The moderating effect of competitive status on the relationship between customer satisfaction and retention. Total Qual. Manag. Bus. Excell. 2019, 30, 721-744. [CrossRef]

10. Montañés-Del-Río, M.Á.; Medina-Garrido, J.A. Determinants of the Propensity for Innovation among Entrepreneurs in the Tourism Industry. Sustainability 2020, 12, 5003. [CrossRef]

11. Huang, F.; Rice, J. The role of absorptive capacity in facilitating open innovation outcomes: A study of Australian SMEs in the manufacturing sector. Int. J. Innov. Manag. 2009, 13, 201-220. [CrossRef]

12. Wincent, J.; Anokhin, S.; Boter, H.K. Network board continuity and effectiveness of open innovation in Swedish strategic small-firm networks. RED Manag. 2009, 39, 55-67.

13. Cammarano, A.; Caputo, M.; Lamberti, E.; Michelino, F. Open innovation and intellectual property: A knowledge-based approach. Manag. Decis. 2016, 55, 1182-1208. [CrossRef]

14. Mina, A.; Bascavusoglu-Moreau, E.; Hughes, A. Open service innovation and the firm's search for external knowledge. Res. Pol. 2014, 43, 853-866. [CrossRef]

15. Barge-Gil, A. Open Strategies and Innovation Performance. Ind. Innov. 2013, 20, 585-610. [CrossRef]

16. Hung, K.-P.; Chou, C. The impact of open innovation on firm performance: The moderating effects of internal R\&D and environmental turbulence. Technovation 2013, 33, 368-380.

17. Laursen, K.; Salter, A.J. Open for Innovation: The role of openness in explaining innovative performance among UK manufacturing firms. Strateg. Manag. J. 2006, 27, 131-150. [CrossRef]

18. Lopes, A.P.V.B.V.; de Carvalho, M.M. Evolution of the open innovation paradigm: Towards a contingent conceptual model. Technol. Forecast. Soc. Chang. 2018, 132, 284-298. [CrossRef]

19. Lichtenthaler, U.; Lichtenthaler, E. A capability-based framework for open innovation: Complementing absorptive capacity. J. Manag. Stud. 2009, 46, 1315-1338. [CrossRef]

20. Amarakoon, U.; Weerawardena, J.; Verreynne, M.L.; Teicher, J. Entrepreneurial behaviour: A new perspective on the role of the HR professional. Pers. Rev. 2019, in press. [CrossRef]

21. Serenko, A.; Bontis, N.; Grant, J. A scientometric analysis of the proceedings of the McMaster world congress on the management of intellectual capital and innovation for the 1996-2008 period. J. Intellect. Capital 2009, 10, 8-21. [CrossRef]

22. Chaston, I. Independent financial advisors: Open innovation and business performance. Serv. Ind. J. 2013, 33, 636-651. [CrossRef]

23. Dayan, R.; Heisig, P.; Matos, F. Knowledge management as a factor for the formulation and implementation of organization strategy. J. Knowl. Manag. 2017, 21, 308-329. [CrossRef]

24. Chapman, E.F.; Sisk, F.A.; Schatten, J.; Miles, E.W. Human resource development and human resource management levers for sustained competitive advantage: Combining isomorphism and differentiation. J. Manag. Organ. 2018, 24, 533-550. [CrossRef]

25. Dost, M.; Arshad, M.; Afsar, B. The influence of entrepreneurial orientation on types of process innovation capabilities and moderating role of social capital. Entrep. Res. J. 2018, 8, 1-5. [CrossRef]

26. Suseno, Y.; Rowley, C. Taking stock of social capital research: Its application in service-oriented firms. Asia Pac. Bus. Rev. 2018, 24, 138-149. [CrossRef]

27. Suseno, Y.; Rowley, C. Social capital in service-oriented firms: Future directions. Asia Pacific Bus. Rev. 2018, 24, 261-271. [CrossRef]

28. Kianto, A.; Sáenz, J.; Aramburu, N. Knowledge-based human resource management practices, intellectual capital and innovation. J. Bus. Res. 2017, 81, 11-20. [CrossRef]

29. Wu, S.-h. The Analysis of the Second Industrial Innovation Survey in Taiwan Area (E96054) [data file]. Available from Survey Research Data Archive. Acad. Sinica 2009. [CrossRef]

30. Bontis, N.; Wu, S.; Tsan, W.N.; Chang, C.C. Intellectual capital system interaction in Taiwan. J. Intellect. Capital 2005, 6, 285-297.

31. Omar, M.K.; Mohd Yusoff, Y.; Kamarul Zaman, M.D. The Effect of Organizational Learning Capability as a Mediating Variable in the Relationship between Green Intellectual Capital and Business Sustainability: Evidence from the Manufacturing Sector. Int. J. Acad. Res. Bus. Soc. Sci. 2019, 9, 337-352. [CrossRef] 
32. Dionne, K.E.; Carlile, P. Opening Innovation: Across Layers of Practices: Developing an Integrative View of the Emergence of Digital Health; Managing Inter-organizational Collaborations: Process Views (Research in the Sociology of Organizations); Emerald Publishing Limited: Bingley, UK, 2019; Volume 64, pp. 213-237.

33. Baron, R.M.; Kenny, D.A. The moderator-mediator variable distinction in social psychological research: Conceptual, strategic, and statistical considerations. J. Personal. Soc. Psychol. 1986, 1, 1173-1182. [CrossRef]

34. Chang, S.J.; van Witteloostuijn, A.; Eden, L. Common Method Variance in International Business Research: Further Reflections. In Research Methods in International Business; Palgrave Macmillan: Cham, Switzerland, 2020; pp. 409-413.

35. Hair, J.F.; Anderson, R.E.; Tatham, R.L.; Black, W.C. Multivariate Data Analysis; Prentice Hall International: Upper Saddle River, NJ, USA, 1998.

36. Aderson, J.C.; Gerbing, D.W. Structural equation modeling in practice: A review and recommended two-step approach. Psychol. Bull. 1988, 103, 411-423. [CrossRef]

(C) 2020 by the authors. Licensee MDPI, Basel, Switzerland. This article is an open access article distributed under the terms and conditions of the Creative Commons Attribution (CC BY) license (http://creativecommons.org/licenses/by/4.0/). 